\title{
Comparative Quality Analysis of Milk Collected from Open Markets and Dairy Industries in Bangladesh
}

\author{
Md. Shabudden Ahamed ${ }^{1 *} \quad$ Munira Khandakar Sadia ${ }^{2} \quad$ K M Formuzul Haque $^{3}$ \\ 1.Department of Food and Nutritional Science, Rajshahi Institute of Biosciences, University of Rajshahi, \\ Bangladesh \\ 2.College of Food Science and Technology, Huazhong Agricultural University, China \\ 3.Department of Food Engineering, NPI University of Bangladesh, Bangladesh
}

\begin{abstract}
The present study was conducted to analysis the quality indicators of cow's milk both in open market and processing industries in Bangladesh. Total 84 samples of fluid milk (15 samples from the open market of each district are Sirajganj, Pabna, Tangail and Dhaka and 6 samples of pasteurized milk of 4 different brands) were collected. The determination of physicochemical properties, microbial quality and presence of adulterant of all milk samples were carried out. Highest average milk fat was found in the raw milk collected from the open market at Dhaka district and in Brand 4 as 4.2\% and 3.55\% respectively. The lowest corrected lactometer reading (CLR) was found in Sirajganj as 25.5. A few of the pasteurized milk and open market milk were being adulterated by skimmed milk, sugar, added water and soda and alcohol respectively. Results pertaining to the enumeration of E.coli, Salmonella and V. Cholera exhibited $56.66 \%, 45 \%$ and $10 \%$ of samples of open market and $12.5 \%, 8.33 \%$ and $4.17 \%$ of samples of brands respectively. Due to unhygienic milking practice and very poor sanitary facilities, the highest amount of total plate count was $7.9 \times 10^{6} \mathrm{cfu} / \mathrm{ml}$ at Sirajganj district.
\end{abstract}

Keywords: Milk quality, Pasteurization, Open market, Adulteration, Food safety

DOI: $10.7176 / \mathrm{FSQM} / 101-05$

Publication date:September $30^{\text {th }} 2020$

\section{Introduction}

Milk is the valuable single most complete food but assuring the quality of milk is a significant issue now a days. It is easily perishable and highly vulnerable to adulteration and microbial contamination. The consumer usually suffers for milk adulteration so they want to get fresh, clean and pure milk and pathogen free (Coitinho, Cassoli, Cerqueira, Silva, Coitinho, \& Machado, 2017; Ghasemi-Varnamkhasti, Ghatreh-Samani, Naderi-Boldaji, Forina, \& Bonyadian, 2017). There are 7,990 number of registered dairy farm in Bangladesh (2009-10). Consumption of milk and milk products is carried out in different ways: directly from the producers, from the vendors and from the commercial milk processors, so there is lot of chance of deterioration. Maintaining high quality milk from local farm to open market is challenging due to unhygienic milking by the farmers, humidity, perilous food chain and adulteration. The quality of raw milk is poor and in threat. At farm level, the unhygienic practices and poor animal husbandry predispose farmers, consumers and the public to risk of contracting milk-borne infections and associated bacterial resistances. Teklemichael et al. (2015) investigate the mean value of $\mathrm{pH}$, specific gravity, titratable acidity, protein, fat, total solids and solids-not-fat contents of 30 milk samples and Iqbal et al. (2016) investigate the microbiological quality of raw milk of 80 samples of Coimbatore district. Faraz et al. (2013) collected a total of sixty samples from the different location and were processed for determination of adulterants, chemical composition and hygienic condition. Adulteration in milk has been a cause of concern for both the Government and the dairy industry at present time in Bangladesh. Milk is most commonly diluted with water and this not only reduces its nutritional value, but contaminated water can also cause additional health problems. The other adulterants used are mainly detergent, foreign fat, starch, sodium hydroxide (caustic soda), sugar, urea, pond water, salt, malt dextrin, sodium carbonate, formalin, and ammonium sulphites. The extensive consumption of milk and dairy products makes these foodstuffs targets for potential adulteration with financial gains for unscrupulous producers (Nicolaou \& Goodacre, 2011).

Nirwal et al. (2013) was conducted a study to analyze the milk quality, adulteration and mastitis infection in milk sold at 30 different regions of Dehradun. Out of 100 milk samples analyzed for adulteration, adulterants found were glucose $(80 \%)$, skim milk powder $(58 \%)$, salt $(51 \%)$ and urea $(35 \%)$ while found negative for formalin, salicylic acid, boric acid, starch, soap and ammonium sulphites. It can cause impairments, heart problems, cancer or even death. While the immediate effect of drinking milk adulterated with urea, caustic soda and formalin is gastroenteritis or severe forms of diarrhea (food poisoning). In the long run, these chemicals in milk adversely affect vital organs such as the liver and kidney resulting in organ failure and/or cancer and thus, untimely loss of life. Due to high water activity and nutritional value of milk, it serves as an excellent medium for the growth of many microorganisms, especially Lactobacillus, Streptococcus, Staphylococcus and Micrococcus sp. Bacteria that have been frequently involved in food borne outbreaks associated with the consumption of milk include Listeria monocytogenes, Salmonella, Campylobacter, Staphylococcus aureus, Bacillus cereus, Escherichia coli 
and Clostridium botulinum. These pathogens can cause illness to humans while others cause spoilage in milk rendering it unsuitable (unsafe) for human consumption (Kivaria, Noordhuizen, \& Kapaga, 2006; Parekh \& Subhash, 2008; Bukuku, 2013). In some cases, infections can cause contamination and even make the milk not proper for use. It can conceal life-threatening hazards when it comes to gastroenteritis, diarrhea, typhoid, or bovinetuberculosis (Al-Khatib \& Al-Mitwalli, 2009). The total count of bacteria in milk has a decisive effect on the quality and safety of dairy products (Khaton, Hasnat, Rahman \& Rahman, 2014). Contamination of milk with high levels of spoilage bacteria is usually unsuitable for further processing since it does not meet the consumer's expectations in terms of health (nutritional value), safety (hygienic quality) and satisfaction (sensory attributes) (Nanu, Latha, Sunil, Prejit, Thomas, \& Venon, 2007). As a result, total viable bacterial counting has become one of the accepted criteria for grading milk intended for consumption and processing for dairy products.

Milk produced under hygienic conditions from healthy animals should not contain more than $5 \times 10^{3} \mathrm{CFU} / \mathrm{ml}$ (Popescu, Borda, Diugan \& Oros, 2014). Whereas total plate counts, total coliform counts and the presence of Escherichia coli and E. coli $\mathrm{O} 157: \mathrm{H} 7$ were determined in 250 samples of kraals and indigenous milk products in the coastal savannah zone of Ghana. Total plate counts exceeded $10^{5} \mathrm{CFU} / \mathrm{ml}$ in $45.2 \%$ of the samples while coliforms exceeded $10^{3} \mathrm{CFU} / \mathrm{ml}$ in $66.0 \%$ and $E$. coli was detected in $11.2 \%$. Antibiotic residues were detected in $3.1 \%$ of raw cow milk samples (Addo, Mensah, Aning, Nartey, Nipah, Bonsu, Akyeh \& Smits, 2011). Pasteurized milk contained acceptable numbers of bacteria in $>90 \%$ of samples indicating pasteurization to be effective in lowering bacterial contamination of milk in processing industry. Spore-forming bacteria are found in a wide range of dairy-associated environments including soil, water, feed, and manure (Scheldeman, Herman, Foster \& Heyndrickx, 2006; Huck, Hammond, Murphy, Woodcock \& Boor, 2007; Ivy, Ranieri, Martin, Bakker, Xavier, Wiedmann \& Boor, 2012; Masiello, Martin, Watters, Galton, Schukken, Wiedmann, Boor, 2014). Management practices significantly associated with increased bulk tank somatic cell count were a lack of use of the California mastitis test at freshening and $>25 \%$ of cows with dirty udders observed in the milking parlor (Giffel, Wagendorp, Herrewegh \& Driehuis, 2002).

High microbial load and adulteration of milk pose a serious threat to public health of Bangladesh where the health literacy is poor and level of awareness is very low. But there is only a few research has done and no standard data to compare the quality of milk. The study was conducted to analysis the physicochemical, nutritional and microbial quality of open market milk and processed milk, to identify the possible source of infectivity from farm to open market and process industry to consumer.

\section{Materials \& Methods \\ 2.1 Sample Collection}

A total 84 samples of which 60 were collected from the 4 open markets of each Sirajganj, Pabna, Tangail and Dhaka district and 24 samples were collected from 4 different dairy processing plants. $250 \mathrm{ml}$ of each sample were collected. Samples are being collected from dairy industries are divided into two sections: raw milk and pasteurized milk. Then, sample were transported to the laboratory in icebox and analyzed immediately on arrival. Each sample of milk $(25 \mathrm{ml})$ was taken and mixed well with $225 \mathrm{ml}$ of sterile peptone water and was serially diluted according to the need (Erdogrul \& Erbilir, 2006).

\subsection{Structured Questionnaire}

Structured questionnaire was distributed to 20 milkmen and 12 worker of processing plants. The questionnaire was aimed to obtain first-hand information on the general awareness of the milkmen, adulteration, sources of cattle feed and hygiene practices. The questionnaire for industrial worker also included the practice of washing the equipment, sanitary practices, training on food hygiene and safety.

\subsection{Physicochemical Analysis}

The physical characteristics and different chemical properties such as lactose, protein, water, and fat of various milk samples were determined shortly after they determinations were carried out according to AOAC 2000. Various physiochemical properties of milk were analyzed and compared to Bangladesh Standard (BDS-1985) and WHO Standards. Conductivity, freezing point are examined for physical analysis; formalin, sugar, acidity, ph, salt for chemical examination and fat, corrected lactometer reading (CLR), solid non fat (SNF), total solid (TS) for nutritional analysis.

\subsection{Microbiological Examination}

The specific medium agar and the supplements were purchased from Oxid, United Kingdom and prepared according to the manufacturer's directions. MYP agar base, with the addition of Polymyxin-B selective supplements, and Mac Conkey agar were prepared for the isolation of B. cereus and E. coli, respectively (AOAC, 1999). For the examination of Salmonella and Campylobacter, Salmonella, Shigella agar and Campylobacter blood free selective agar base, with the addition of Campylobacter selective supplement, were used (AOAC, 2001). 
The inoculated plates were then incubated at $35^{\circ} \mathrm{C}$ for $24-48 \mathrm{hr}$. Coliform count was carried using Most Probable Number (MPN) technique. For total coliform count (TCC), $1 \mathrm{ml}$ of each of the three consecutive dilution tubes was inoculated into tubes containing lactose broth (LB) with Durham's tubes and incubated at $35^{\circ} \mathrm{C}$ for 48 hr (Uma, Chandrakanth, Indu, Nagalakshmi \& Usha, 2009). From positive cultures, a loop-full of suspension was transferred to tubes containing $2 \%$ Brilliant Green LB and incubated at $35^{\circ} \mathrm{C}$ for $48 \mathrm{hr}$. Positive tube were considered positive to coliform and then CC calculated using MPN table (Blodgett, 2010). Each presumptive positive tube of LB was transferred to tubes of E. coli broth tubes and incubated for $48 \mathrm{hr}$ at $45.5^{\circ} \mathrm{C}$. Production of gas in an E. coli broth culture was determined as positive for fecal coliform.

\subsection{Effect of Sampling Time on Bacterial Load}

To analyze the effect of sampling time on the total viable bacterial count (TVC), sampling time was separated into two sections: samples were collected during the morning and afternoon period.

\subsection{Test of Adulteration}

Raw milk quality and determination of adulterants at the collection point also a major concern of this study. To determine whether the samples were adulterated by mixing various agents, we analyzed the presence of sugar, starch, salt, soda, alcohol, formaldehyde and added water as per AOAC 2000.

\subsection{Effect of Industrial Processing on Bacterial Count}

Raw milk is collected from the chilling center through tanker and cool at $5^{\circ} \mathrm{C}$. Then the milk is taken for standardization, mixing, homogenization, pasteurization, cooling and packaging. $250 \mathrm{ml}$ of sample was taken each steps of processing to calculate the bacterial count of milk in different processing steps. TPC and TCC were examined to analysis the effect of thermal process.

\subsection{Data Analysis}

Mean separated and significance difference determined at the 5\% level were analyzed by analysis of variance using SPSS software version 16.0.

\section{Results and Discussion}

\subsection{Questionnaire Survey}

A total 20 cattle farm and 4 dairy industries were interviewed to obtain primary data on milking practices, sources of cattle feed, hygiene practices, quality analysis, chain of marketing etc. $95 \%$ of the farm on the bank of Baral River at Shahjadpur, Sirajganj have no shade for cattle. They keep them in a closed bamboo fenced farm called "Bathan". In there all the cattle drink water from river source which is polluted with industrial effluents. Luciana et al visited a group of 22 dairy farms were twice (winter and summer) in order to collect bulk tank milk and postrinse water samples and swabs from liners and milk receiver (Bava, Zucali, Sandrucci, Brasca, Vanoni, Zanini, \& Tamburini, 2011). A study showed that, total plate count in farmer's hand was $178 \mathrm{CFU} / \mathrm{ml}$ and in milking pot it was $94 \mathrm{cfu} / \mathrm{ml}$. Total coliform counts in farmer's hand was $44 \mathrm{CFU} / \mathrm{ml}$ and in milking pot $27 \mathrm{CFU} / \mathrm{ml}$ (Prodhan, Alam, Sadia, Sultana, Hye, Ahamed, 2016). In this study, $>91 \%$ of milkmen were used fresh water for washing milk-pot and $<7 \%$ use warm water or detergent. The presence of insect especially flies are in acute condition in the local farm. When the cattle become sick, the milkmen purchase antibiotic or other medicine according to the recommendation of medicine store.

A survey questionnaire targeting 52 Municipal health services managers or designated persons (directly responsible for milk control) at the various metropolitan municipalities (metros) and district municipalities (DMs) in South Africa was conducted (Agenbag \& Lues, 2009). Miller et al. (2015) examined the association between farm management practices and mesophilic and thermophilic spore-formers in raw milk. Farm management factors associated with fewer mesophilic spores, the most abundant spore type found in raw milk, included larger herd size, the use of sawdust bedding, and not fore-stripping during pre-milking routine. $64 \%$ of worker of the industries abide by hygiene which is monitored by the safety and sanitation monitoring committee. Male worker are $37 \%$ less conscious in using hand and mouth gloves than female worker comparatively. In farm level, $<5 \%$ of measures are maintained and the hygiene condition was extremely poor.

\subsection{Organoleptic, Physical and Major Proximate Analysis}

In organoleptic test of collected milk, all the appearance (color, flavour, taste) were examined. All the color of pasteurized milk is creamy white and the color of raw milk is yellowish white. Rashedul et al and Monem et al found the sample collected from Mymensingh and Bogura district respectively were yellowish white also (Rashedul, 2012; Monem, 2012). The shelf life of pasteurized milk was 7 days. 
Table 1: Major proximate analysis of raw milk and processed milk of selected open markets and brands

\begin{tabular}{|c|c|c|c|c|c|c|c|c|c|c|c|c|c|}
\hline \multirow[t]{2}{*}{ Sampletype } & \multirow{2}{*}{$\begin{array}{l}\text { Na of } \\
\text { sample }\end{array}$} & \multicolumn{4}{|c|}{ MRFat } & \multicolumn{4}{|c|}{ QR } & \multicolumn{4}{|c|}{ SNF } \\
\hline & & AvergeFat & $\begin{array}{l}\text { Lower } \\
\text { bounday }\end{array}$ & $\begin{array}{l}\text { Upper } \\
\text { bounday }\end{array}$ & $p$ Value & $\begin{array}{l}\text { Mea } \\
\text { npH }\end{array}$ & $\begin{array}{l}\text { Lower } \\
\text { bounday }\end{array}$ & $\begin{array}{c}\text { Upper } \\
\text { bounday }\end{array}$ & $p$ VVahe & $\begin{array}{l}\text { Averge } \\
\text { SNF }\end{array}$ & $\begin{array}{l}\text { Lomer } \\
\text { bounday }\end{array}$ & $\begin{array}{l}\text { Upper } \\
\text { boundav }\end{array}$ & $p$-Value \\
\hline $\mathrm{OM}_{\mathrm{S}}$ & 15 & 4.05 & 3.9 & 4.2 & 0.21 & $\begin{array}{l}25 . \\
5\end{array}$ & 24.5 & 27 & 0.19 & 7.46 & 7.20 & 8.0 & 0.318 \\
\hline$\overline{\mathrm{OM}_{\mathrm{P}}}$ & 15 & 4.0 & 4.0 & 4.15 & & 26 & 25.5 & 28.5 & & 7.63 & 7.41 & 7.88 & \\
\hline $\mathrm{OM}_{\mathrm{T}}$ & 15 & 3.8 & 3.78 & 4.1 & & $\begin{array}{l}26 . \\
5\end{array}$ & 26 & 27 & & 7.90 & 7.17 & 8.1 & \\
\hline $\mathrm{OM}_{\mathrm{D}}$ & 15 & 4.2 & 4.1 & 4.7 & & 27 & 26.5 & 29 & & 7.16 & 6.90 & 7.92 & \\
\hline Brand 1 & 6 & 3.5 & 3.50 & 3.60 & & 28 & 27.5 & 28 & & 8.15 & 7.92 & 8.34 & \\
\hline Brand 2 & 6 & 3.5 & 3.45 & 3.55 & & 29 & 27 & 29.5 & & 8.02 & 8.01 & 8.15 & \\
\hline Brand 3 & 6 & 3.5 & 3.5 & 3.5 & & 28 & 26.5 & 28 & & 7.95 & 7.82 & 8.10 & \\
\hline Brand 4 & 6 & 3.55 & 3.5 & 3.55 & & 28 & 28 & 29 & & 8.15 & 8.00 & 8.20 & \\
\hline
\end{tabular}

$\mathrm{OM}_{\mathrm{S}}=$ Open Market of Sirajganj; $\mathrm{OM}_{\mathrm{P}}=$ Open Market of Pabna; $\mathrm{OM}_{\mathrm{T}}=$ Open Market of Tangail; $\mathrm{OM}_{\mathrm{D}}=\mathrm{Open}$ Market of Dhaka district; CLR = Corrected Lactometer Reading; SNF= Solid non Fat in milk.

The physical and major proximate analysis of selected local farm at Sirajganj, Pabna, Tangail and Dhaka district and 4 commercial brand of fluid milk available in Bangladesh in table 1. Islam et al (2016) studied the milk samples collected from Kakrait Bazar, Tangail district were superior to other markets in terms of fat $(36.83 \pm 0.29$ $\left.\mathrm{gkg}^{-1}\right)$, protein $\left(34.17 \pm 1.26 \mathrm{gkg}^{-1}\right)$, lactose $\left(45.72 \pm 1.02 \mathrm{gkg}^{-1}\right)$ and total solid $\left(124.72 \pm 1.95 \mathrm{gkg}^{-1}\right)$ content. In the present study, milk samples collected from the open market contains high quantity of milk fat $(3.8-4.2 \%)$ than the commercial brands. Statistical analysis showed that there was no significant difference $(\mathrm{p}<0.01)$ within the protein content of different milk samples (Motta, Hoff, Barreto, Andrade, Lorenzini, Meneghini, \& Pizzolato, 2014). But the CLR and SNF of open market milk is lower than the commercial brands.

Table 2: Physicochemical analysis of raw milk and processed milk of selected open markets and brands

\begin{tabular}{|c|c|c|c|c|c|c|c|c|c|c|c|c|c|}
\hline \multirow[t]{2}{*}{ Sampletype } & \multirow{2}{*}{$\begin{array}{l}\text { Naof } \\
\text { sample }\end{array}$} & \multicolumn{4}{|l|}{$\mathrm{pH}$} & \multicolumn{4}{|l|}{ Conductivity } & \multicolumn{4}{|l|}{ Freeringoint } \\
\hline & & $\begin{array}{l}\text { Mean } \\
\text { pH }\end{array}$ & $\begin{array}{l}\text { Lower } \\
\text { boundary }\end{array}$ & $\begin{array}{l}\text { Upper } \\
\text { boundany }\end{array}$ & $p$ Value & $\begin{array}{l}\text { Mean } \\
\text { Conduxinity }\end{array}$ & $\begin{array}{l}\text { Lower } \\
\text { bounday }\end{array}$ & $\begin{array}{l}\text { Upper } \\
\text { bounday }\end{array}$ & $\begin{array}{l}p \\
\text { Value } \\
\text { Valu }\end{array}$ & $\begin{array}{l}\text { Mean freeing } \\
\text { point }\end{array}$ & $\begin{array}{l}\text { Lower } \\
\text { boundary }\end{array}$ & $\begin{array}{l}\text { Upper } \\
\text { boumbay }\end{array}$ & $p$ VVahre \\
\hline $\mathrm{OM}_{\mathrm{s}}$ & 15 & 6.63 & 6.22 & 6.78 & \multirow[t]{8}{*}{0.19} & 3.95 & 3.33 & 4.15 & \multirow{8}{*}{$\begin{array}{l}0.1 \\
8\end{array}$} & -0.509 & -0.512 & -0.507 & \multirow[t]{8}{*}{0.343} \\
\hline $\mathrm{OM}_{\mathrm{P}}$ & 15 & 6.71 & 5.45 & 6.80 & & 3.85 & 3.71 & 3.98 & & -0.517 & -0.520 & -0.512 & \\
\hline $\mathrm{OM}_{\mathrm{T}}$ & 15 & 6.74 & 5.67 & 6.76 & & 4.01 & 3.87 & 4.16 & & -0.516 & -0.524 & -0.508 & \\
\hline $\mathrm{OM}_{\mathrm{D}}$ & 15 & 6.82 & 6.62 & 6.86 & & 4.14 & 3.86 & 4.21 & & -0.505 & -0.515 & -0.510 & \\
\hline Brand 1 & 4 & 6.73 & 6.65 & 6.81 & & 4.37 & 4.13 & 4.45 & & -0.561 & -0.572 & -0.548 & \\
\hline Brand 2 & 4 & 6.72 & 6.48 & 6.78 & & 4.46 & 4.35 & 4.56 & & -0.556 & -0.581 & -0.562 & \\
\hline Brand 3 & 4 & 6.62 & 6.58 & 6.73 & & 4.10 & 3.94 & 4.27 & & -0.572 & -0.586 & -0.565 & \\
\hline Brand 4 & 4 & 6.56 & 6.13 & 6.62 & & 4.26 & 4.01 & 4.46 & & -0.515 & -0.529 & -0.512 & \\
\hline
\end{tabular}

Following table 2 showed the physicochemical test of selected open market and commercial milk brands. The $\mathrm{pH}$ of OMP and OMD is 5.45 and 5.67 respectively which is slightly lower. Due to lack of chilling storage facilities and warm weather the milk of open market make lower $\mathrm{pH}$. Brand 2 showed the highest level of mean conductivity is 4.46. The mean freezing point of the milk found in Sirajganj district, Dhaka district and Brand 4 is lower as $0.509,-0.505$ and -0.515 respectively.

3.3 Quality/safety status of milk samples according to Bangladesh Standard (1702:2002)

Table 3: Quality analysis of milk according to the Bangladesh Standards

\begin{tabular}{|l|l|c|c|c|c|c|c|c|c|}
\hline Characteristics & $\begin{array}{l}\text { Bangladesh } \\
\text { Standards }\end{array}$ & OMs & OMP & $\mathbf{O M}_{\mathbf{T}}$ & $\mathbf{O M}_{\mathbf{D}}$ & $\begin{array}{c}\text { Brand } \\
\mathbf{1}\end{array}$ & $\begin{array}{c}\text { Brand } \\
\mathbf{2}\end{array}$ & $\begin{array}{c}\text { Brand } \\
\mathbf{3}\end{array}$ & $\begin{array}{c}\text { Brand } \\
\mathbf{4}\end{array}$ \\
\hline Fat & $\begin{array}{l}3.50 \% \\
\text { (min.) }\end{array}$ & 4.05 & 4.0 & 3.8 & 4.2 & 3.5 & 3.5 & 3.5 & 3.55 \\
\hline CLR & 28 (min.) & 25.5 & 26 & 26.5 & 27 & 28 & 29.5 & 28 & 29 \\
\hline SNF & 8 (min.) & 7.46 & 7.63 & 7.90 & 7.16 & 8.15 & 8.02 & 7.95 & 8.15 \\
\hline Acidity & $0.15(\max )$. & 0.14 & 0.15 & 0.14 & 0.15 & 0.15 & 0.15 & 0.15 & 0.14 \\
\hline pH & $6.6-6.8$ & 6.63 & 6.71 & 6.74 & 6.82 & 6.73 & 6.72 & 6.62 & 6.56 \\
\hline Adulterant & $-(\mathrm{ve})$ & $-(\mathrm{ve})$ & $+(\mathrm{ve})$ & $-(\mathrm{ve})$ & $+(\mathrm{ve})$ & $-(\mathrm{ve})$ & $+(\mathrm{ve})$ & $+(\mathrm{ve})$ & $-(\mathrm{ve})$ \\
\hline $\begin{array}{l}\text { Total Plate } \\
\text { Count }\end{array}$ & $<20000 / \mathrm{ml}$ & $\begin{array}{c}7.9 \\
\mathrm{x} 10^{6}\end{array}$ & $\begin{array}{c}6.2 \\
\mathrm{x} 10^{6}\end{array}$ & $\begin{array}{c}5.8 \\
\mathrm{x} 10^{6}\end{array}$ & $\begin{array}{c}4.6 \\
\mathrm{x} 10^{6}\end{array}$ & 125 & 485 & 675 & 14500 \\
\hline Total Coliform & $<10 / \mathrm{ml}$ & $\begin{array}{c}4.1 \\
\mathrm{x} 10^{6}\end{array}$ & $\begin{array}{c}3.2 \\
\mathrm{x} 10^{6}\end{array}$ & $\begin{array}{c}4.6 \\
\mathrm{x} 10^{6}\end{array}$ & $\begin{array}{c}3.8 \\
\mathrm{x} 10^{6}\end{array}$ & 0 & 2 & 5 & 8 \\
\hline
\end{tabular}

Table 3 showed the comparison of pasteurized and raw milk with the Bangladesh Standard 1702:2002. Among the pasteurized milk of 4 brands and raw milk of the open market, the highest amount of fat found in Dhaka and the highest amount of CLR found in Brand 2 is 29.5. According to the Bangladesh Standard (BDS) (BSTI, 2002), both the fat and CLR are above the standard limit. The SNF, acidity and $\mathrm{pH}$ are approximate to the standard also. High quality milk essentially needs to have less than 0.14 percent acidity (Popescu \& Angel, 2009). The average acidity of the pasteurized milk samples ranged from $0.169 \pm 0.010$ to $0.200 \pm 0.013$ during the six days examination period, where BSTI (2002) allows a maximum acidity of $0.15 \%$ for the pasteurized milks (Dey \& Karim, 2013). Milk sample found in Pabna and Dhaka are contaminated with adulterants as soda and skimmed milk powder respectively. Pasteurized milk sample of Brand 2 and Brand 3 were found adulterated with added water and skimmed milk powder also. The distribution of the total viable micro-organisms ranged 
from $>10^{4} \mathrm{CFUml}^{-1}$ to $10^{7} \mathrm{CFUml}^{-1}$ with the highest recorded count at $6.08 \times 10^{7} \mathrm{CFUml}^{-1}$ which is much higher than the legislative standard of $5 \times 10^{4} \mathrm{CFUml}^{-1}$ for raw milk intended for consumption (Lues, Beer, Jacoby, Jansen \& Shale, 2010). The Coliform limits in the raw milk accepted internationally are less than 100 cell $/ \mathrm{ml}$ (Salman, 2011; Shojaei \& Yadollahi, 2008). Surprisingly found that total plate count and total coliform in local raw milk is $7.9 \times 10^{6}$ to $4.6 \times 10^{6} \mathrm{cfu} / \mathrm{ml} \& 4.6 \times 10^{6}$ to $3.2 \times 10^{6} \mathrm{cfu} / \mathrm{ml}$ respectively where the BDS is less than $20000 / \mathrm{ml} \& 10 / \mathrm{ml}$ respectively. Beside that in pasteurized milk total plate count and total coliform were 125 $14500 \mathrm{cfu} / \mathrm{ml}$ and nil to $8 \mathrm{cfu} / \mathrm{ml}$ respectively.

\subsection{Adulteration Test of Milk of Different Sources}

Islam et at. (2018) collected raw milk sample in three different market of Jamalpur district, Bangladesh and observed that there was no adulteration in any of the collected raw milk samples. Raw milk had been adulterated with water and sugar found in Bangladesh by T. J. Hossain et al. (2010). Figure 1 showed the adulteration test result of fluid milk in different sources of open market and commercial brands. Positive result found sugar test in $33 \%$ and $66 \%$ sample of Brand 2 and Brand 3 sample respectively.

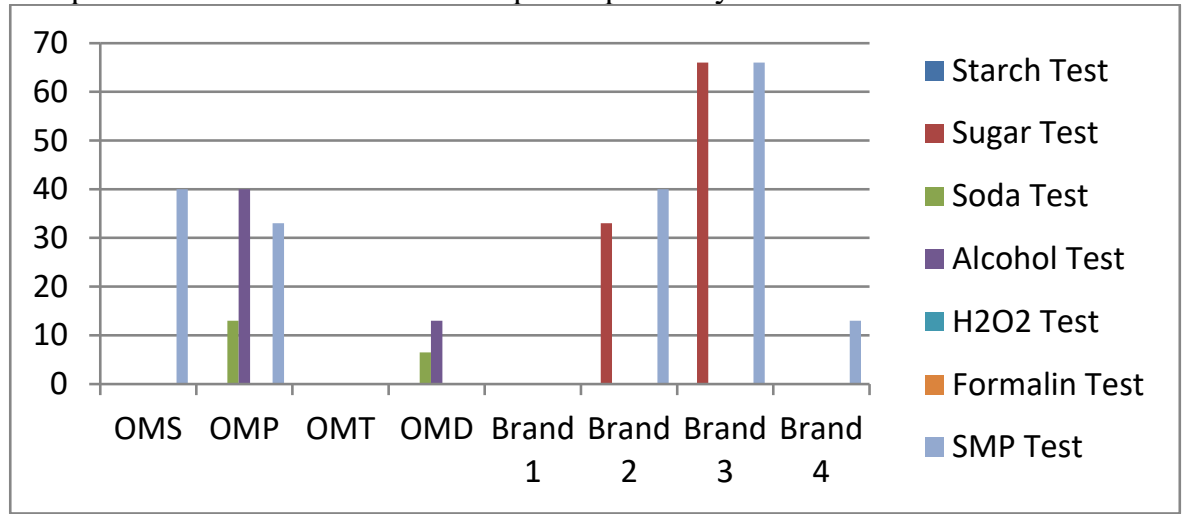

Figure 1: Adulteration test of milk of different sources

Soda found in 13\% sample of open market of Pabna and 6.5\% sample of Dhaka district. 40\% sample of open market of Pabna and 13\% sample of Dhaka contain below the standard limit of alcohol. To enhance the specific gravity of fluid milk skimmed milk powder were commonly found in $40 \%, 33 \%, 40 \%, 66 \%$ and $13 \%$ sample of Open market in Sirajganj, Pabna, Brand 2, Brand 3 and Brand 4. is showed negative results. Naturally the cow's milk are milking in afternoon contain less fat and CLR than morning. SMP and sugar are added to milk to increase CLR. Popescu et al. (2009) reported that every tank truck of milk is carefully checked concerning the presence of antibiotics prior to the tank being unloaded in USA but there is no routine check of antibiotics in processing of milk in Bangladesh.

\subsection{Microbial Safety Status of Milk}

Table 4: Detection of E. coli, Salmonella and V. Cholera in liquid milk collected from the local markets of Bangladesh

\begin{tabular}{|l|l|l|l|l|l|l|}
\hline \multirow{2}{*}{ No. } & \multicolumn{2}{|c|}{ E.coli } & \multicolumn{2}{c|}{ Salmonella } & \multicolumn{2}{c|}{ V. cholera } \\
\cline { 2 - 7 } & Open market & Process milk & Open market & Process milk & Open market & Process milk \\
\hline 1 & $11 / 15$ & $1 / 6$ & $6 / 15$ & $0 / 6$ & $3 / 15$ & $0 / 6$ \\
\hline 2 & $8 / 15$ & $0 / 6$ & $7 / 15$ & $0 / 6$ & $1 / 15$ & $0 / 6$ \\
\hline 3 & $9 / 15$ & $0 / 6$ & $9 / 15$ & $1 / 6$ & $1 / 15$ & $0 / 6$ \\
\hline 4 & $6 / 15$ & $2 / 6$ & $5 / 15$ & $1 / 6$ & $1 / 15$ & $1 / 6$ \\
\hline Total & $34 / 60(56.66 \%)$ & $3 / 24(12.5 \%)$ & $27 / 60(45 \%)$ & $2 / 24(8.33 \%)$ & $6 / 60(10 \%)$ & $1 / 24(4.17 \%)$ \\
\hline
\end{tabular}

Table 4 shows, the presence of E.coli, salmonella and V.cholera are detected in selected samples. A total 84 sample are examined which are divided in 2 categories as open market and brands. Marjan et al. (2014) state that out of 80 samples, 74 were found pathogens within a range of 102-104 cfu/ml, including Escherichia coli, Salmonella spp., Staphylococcus aureus and Vibrio spp. In the present study, E. coli, Salmonella and V. cholera are found in $56.66 \%, 45 \%$ and $10 \%$ samples in open market respectively. $12.5 \%, 8.33 \%$ and $4.17 \%$ sample of brands are found positive result in detection of E.coli, salmonella and V. Cholera respectively. 
Table 5: Detection of TPC, TCC and FCC in milk sample

\begin{tabular}{|c|c|c|c|c|c|c|c|c|c|c|c|c|c|}
\hline \multirow{2}{*}{$\begin{array}{l}\text { Sample } \\
\text { type }\end{array}$} & \multirow{2}{*}{$\begin{array}{l}\text { No. of } \\
\text { sample }\end{array}$} & \multicolumn{4}{|c|}{ Total Plate Count (TPC) } & \multicolumn{4}{|c|}{ Total Coliform Count (TCC) } & \multicolumn{4}{|c|}{ Fecal Coliform Count (FCC) } \\
\hline & & $\begin{array}{l}\text { Mean } \\
\text { TPC } \\
(\mathrm{cfu} / \mathrm{ml})\end{array}$ & $\begin{array}{l}\text { Lower } \\
\text { boundary } \\
\text { (cfu/ml) }\end{array}$ & $\begin{array}{l}\text { Upper } \\
\text { boundary } \\
\text { (cfu/ml) }\end{array}$ & $\begin{array}{l}p \text { - } \\
\text { Value }\end{array}$ & $\begin{array}{l}\text { Mean } \\
\text { TCC } \\
\text { (cfu/ml) }\end{array}$ & $\begin{array}{l}\text { Lower } \\
\text { boundary } \\
\text { (cfu/ml) }\end{array}$ & $\begin{array}{l}\text { Upper } \\
\text { boundary } \\
\text { (cfu/ml) }\end{array}$ & $\begin{array}{l}p \text { - } \\
\text { Value }\end{array}$ & $\begin{array}{l}\text { Mean } \\
\text { FCC } \\
\text { (cfu/ml) }\end{array}$ & $\begin{array}{l}\text { Lower } \\
\text { boundary } \\
\text { (cfu/ml) }\end{array}$ & $\begin{array}{l}\text { Upper } \\
\text { boundary } \\
\text { (cfu/ml) }\end{array}$ & $\begin{array}{l}p \text { - } \\
\text { Value }\end{array}$ \\
\hline $\mathrm{OM}_{\mathrm{S}}$ & 15 & $7.9 \times 10^{6}$ & $6.8 \times 10^{6}$ & $9.3 \times 10^{6}$ & \multirow[t]{8}{*}{0.5} & $4.1 \times 10^{6}$ & $3.1 \times 10^{6}$ & $5.5 \times 10^{6}$ & \multirow[t]{8}{*}{0.6} & $3.0 \times 10^{6}$ & $2.9 \times 10^{6}$ & $3.6 \times 10^{6}$ & \multirow[t]{8}{*}{0.01} \\
\hline $\mathrm{OM}_{\mathrm{P}}$ & 15 & $6.2 \times 10^{6}$ & $3.9 \times 10^{6}$ & $8.7 \times 10^{6}$ & & $3.2 \times 10^{6}$ & $2.7 \times 10^{6}$ & $4.8 \times 10^{6}$ & & $2.5 \times 10^{6}$ & $2.0 \times 10^{6}$ & $4.1 \times 10^{6}$ & \\
\hline $\mathrm{OM}_{\mathrm{T}}$ & 15 & $5.8 \times 10^{6}$ & $2.8 \times 10^{6}$ & $7.1 \times 10^{6}$ & & $4.6 \times 10^{6}$ & $2.4 \times 10^{6}$ & $6.8 \times 10^{6}$ & & $3.3 \times 10^{6}$ & $1.6 \times 10^{6}$ & $4.2 \times 10^{6}$ & \\
\hline $\mathrm{OM}_{\mathrm{D}}$ & 15 & $4.6 \times 10^{6}$ & $3.2 \times 10^{6}$ & $6.9 \times 10^{6}$ & & $3.8 \times 10^{6}$ & $3.5 \times 10^{6}$ & $4.1 \times 10^{6}$ & & $3.1 \times 10^{6}$ & $2.7 \times 10^{6}$ & $3.6 \times 10^{6}$ & \\
\hline Brand 1 & 6 & 125 & 80 & 250 & & $\mathrm{ND}^{* *}$ & - & - & & ND & - & - & \\
\hline Brand 2 & 6 & 485 & 110 & 780 & & 2 & 2 & 3 & & ND & - & - & \\
\hline Brand 3 & 6 & 675 & 380 & 1200 & & 5 & 4 & 6 & & 1 & 1 & 2 & \\
\hline Brand 4 & 6 & 14500 & 870 & 22000 & & 8 & 7 & 12 & & 2 & 1 & 4 & \\
\hline
\end{tabular}

$* \mathrm{cfu}=$ colony forming unit; $* * \mathrm{ND}=$ not detected

Table 5 showed the microbial enumeration of milk for TPC, TCC and FCC. The presence of these organisms in milk and milk products is an indication of unsanitary production andlor improper handling of either milk or milk utensils (EL-zubeir \& Ahmed, 2007). Dehinenet et al. (2013) reported that the mean total bacterial count $(\mathrm{TBC} / \mathrm{ml})$, total coliform count $(\mathrm{TCC} / \mathrm{ml})$ and somatic cell count $(\mathrm{SCC})$ were $1.1 \times 10^{8}, 3.0 \times 10^{4}$ and $5.5 \times 10^{5}$ respectively in Ethiopia. The open market contain higher amount of TPC, TCC and FCC than all the brands. Maximum TPC found in the samples collected from Sirajganj was $7.9 \times 10^{6} \mathrm{cfu} / \mathrm{ml}$. The unhygienic condition in milking and the poor sanitary practices of milkmen are the cause of higher TPC, TCC and FCC. The sample collected from the open markets of Tangail contain highest amount of TCC and FCC were $4.6 \times 10^{6}$ and $3.3 \times 10^{6}$ $\mathrm{cfu} / \mathrm{ml}$ respectively. It was surprisingly found that the brands contain only $125-14500 \mathrm{cfu} / \mathrm{ml}$ due to pasteurization at $85-90^{\circ} \mathrm{C}$ for 15 seconds. TCC and FCC found in Brand 1 were nil. Brand 4 contains the higher amount of TPC, TCC and FCC among the all 4 brands but all brands complies with Bangladesh Standard (BDS).

3.6 Effect of thermal process on the bacterial growth of milk in different processing steps 3.6.1 Prevalence and enumeration of total plate count in processing steps

\section{Total Plate Count (CFU/ml)}

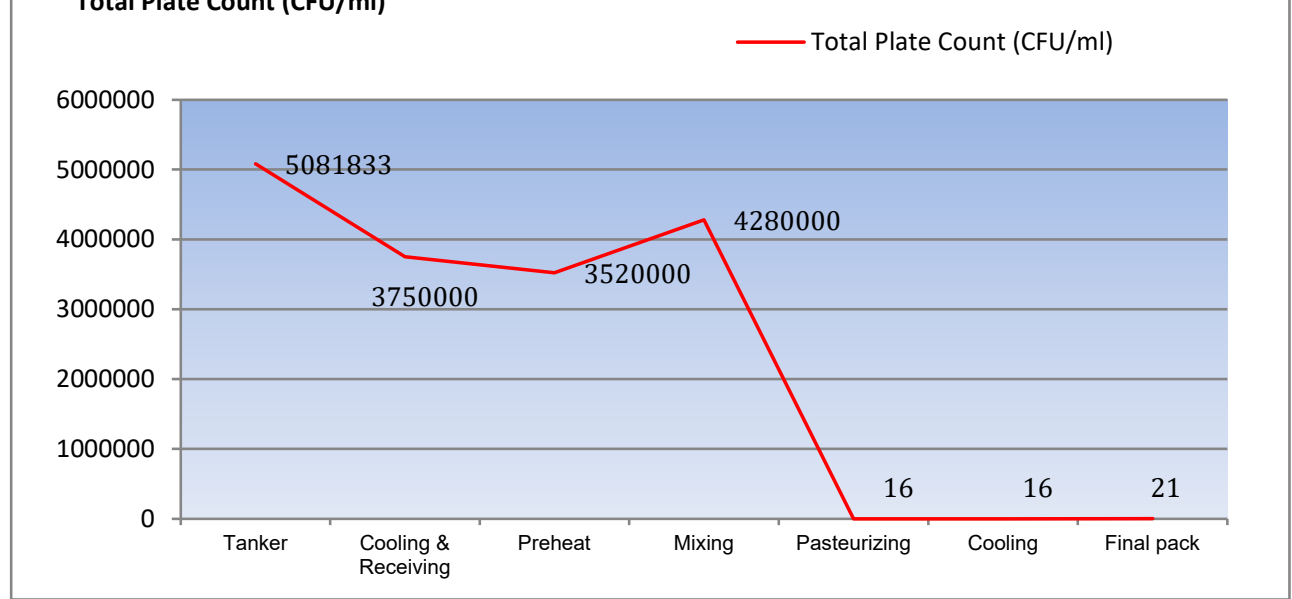

Figure 2: Distribution of total plate count in different steps of Processing of milk

The effect of thermal processing i.e. pasteurization on the microbial quality milk is showed [Figure 2]. Most fluid milk consumed in the United States is HTST pasteurized (i.e., $72^{\circ} \mathrm{C}$ for $15 \mathrm{~s}$ ) with an anticipated shelf-life of 14 to 21 days (Murphy, Martin, Barbano, \& Wiedmann, 2016). The consumption of milk that is not pasteurized increases the risk of contracting diseases (Angulo, Lejeune, Rajala-Schultz, 2009). The sample was taken in all the possible way of increasing or decreasing of microbial count. The TPC of taken sample was $5.08 \times 10^{6} \mathrm{cfu} / \mathrm{ml}$ which collected from milk tanker at $5^{\circ} \mathrm{C}$. In the receiving section of the processing industry, the milk is passing through the heat exchanger to lose heat to $2^{\circ} \mathrm{C}$ and goes to receive tank. The total plate count in cooling section was $3.75 \times 10^{6} \mathrm{cfu} / \mathrm{ml}$. Milk is then pre-heated at $40-45^{\circ} \mathrm{c}$ and the total counts decrease to $3.52 \times 10^{6} \mathrm{cfu} / \mathrm{ml}$. In Bangladesh, most of the processes of milk are semi-manual. In the mixing section, fat separated, water added and due to manual mixing the TPC increase to $4.3 \times 10^{6} \mathrm{cfu} / \mathrm{ml}$. Then it passes through the homogenizer and pasteurized at $85-90^{\circ} \mathrm{C}$ for $15-20$ seconds. At this stage, total plate counts drastically decreases to $16 \mathrm{cfu} / \mathrm{ml}$ only. Then the milk cooled to $4^{0} \mathrm{C}$. Milk is then passes through filling machine and pack finally. The final product contains $21 \mathrm{cfu} / \mathrm{ml}$ of total plate counts and it stored. 


\subsubsection{Prevalence and enumeration of total coliform count in processing steps}

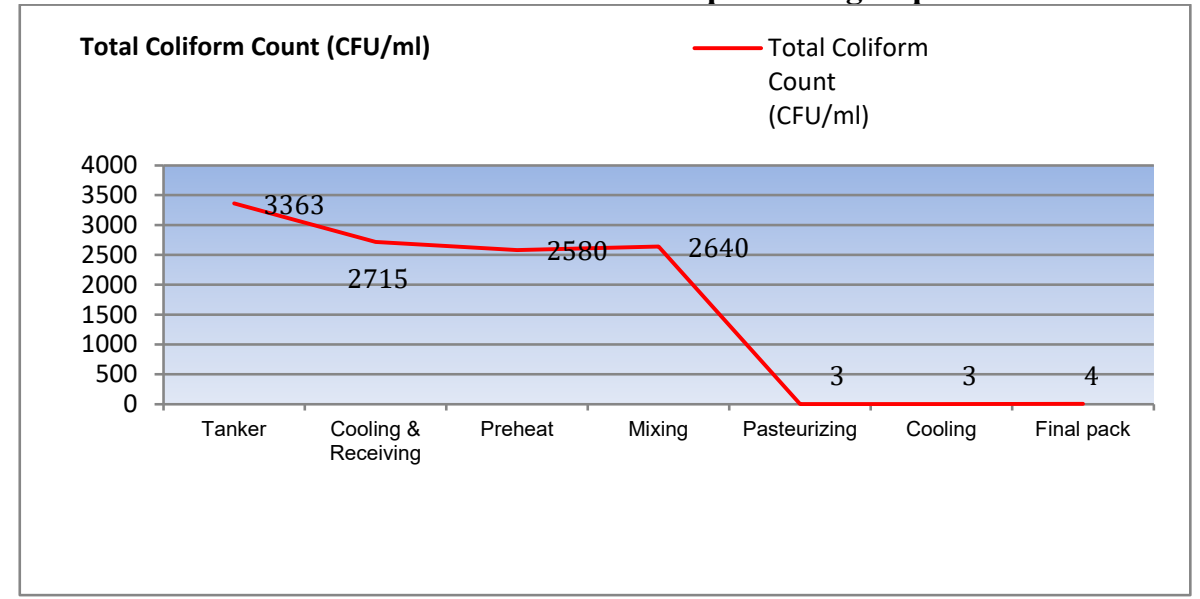

Figure 3: Distribution of total coliform count in different steps of Processing of milk

Figure 3 showed the average Total Coliform Count (TCC) found in each steps of processing line. The shelflife at these pasteurization temperatures was more dependent on other factors such as bacterial load, postpasteurization contamination, and storage conditions (Gandy, Schilling, Coggins, White, Yoon \& Kamadia, 2008). Similarly, samples taken from different processing steps to detect TCC. The raw milk sample contain $3363 \mathrm{cfu} / \mathrm{ml}$ of TCC which are decrease to $2715 \mathrm{cfu} / \mathrm{ml}$ in cooling, $2580 \mathrm{cfu} / \mathrm{ml}$ in pre-heat steps and increase to $2640 \mathrm{cfu} / \mathrm{ml}$ in mixing steps. Significantly, $3 \mathrm{cfu} / \mathrm{ml}$ of TCC found after pasteurization and the final pack contain $4 \mathrm{cfu} / \mathrm{ml} \mathrm{of}$ TCC.

\section{Conclusion}

The present study revealed nutritional, physicochemical and microbial quality of milk being sold at open market and the pasteurized milk of different brands of Bangladesh. The average milk fat percentage in open market is slightly higher in raw milk sold in open market but CLR is lower than the pasteurized milk. Usually adulterant were not found in commercial milk except SMP, Sugar and added water is found to improve the CLR and taste of milk. But soda and alcohol was found in open market milk. Most of the farmers and milkmen are illiterate and they have not enough knowledge about personal hygiene and sanitary practices and unconscious about food safety. The sources of pathogenic bacteria come from natural source and unhygienic handling of milk especially improper hand washing of milkman and the unhygienic condition of cows and milking pot. It is remarkably enumerated that the heat treatment and immediate cooling are the most effective ways for microbial lessening of raw milk during industrial processing. It was surprisingly found that the average TPC and TCC come to least and very acceptable quantity in the pasteurized milk. It can be recommend that, regular monitoring should carried out by processing industries to ascertain the physiochemical characteristics including adulteration parameters and nutritional quality of raw milk. In farm level, different initiative should take to establish sanitary facilities for milkmen, arrange targeted training for milkmen and worker on safe farming \& hygiene practices and ensure safe drinking water facilities for cattle. To ensure the milk quality requires the necessity and greater emphasis on regulatory aspects with advanced methods of analysis and monitoring milk production and processing have set new goals for quality assurance and food safety.

\section{Conflict of Interest}

The authors declare no conflict of interest for this study.

\section{References}

Addo, K. K., Mensah, G. I., Aning, K. G., Nartey, N., Nipah, G. K., Bonsu, C., Akyeh, M. L. \& Smits, H. L. (2011). Microbiological quality and antibiotic residues in informallymarketed raw cow milk within the coastal savannah zoneof Ghana, Tropical Medicine and International Health, 16(2), 227-232.

Agenbag, MHA, Lues, L. \& Lues JFR. (2009) Compliance of local government towards controlling the informal milk-producing sector in South Africa. Environ. Health. Res., 19(5), 379-388.

Al-Khatib, I.A. \& Al-Mitwalli, S.M. (2009). Microbiological quality and sample collection policy for dairy products in Ramallah and Al-Bireh district, Palestine. Eastern Mediterranean Health Journal, 15(3), 709716.

Angulo, F. J., LeJeune J. T., \& Rajala-Schultz, P. J. (2009). Unpasteurized Milk: A Continued Public Health Threat Oxford journals Medicine \& Health Clinical Infectious Diseases, 48(1), 93-100.

AOAC, (1999). Official Method 996.09: Escherichia coli O157:H7 in Selected Foods (EHEC Visual 
Immunoprecipitate Assay (VIP)), AOAC International, Gaithersburg, Maryland.

AOAC, (2001). Official Method 998.09: Salmonella in Foods (TECRA Salmonella Visual Immunoassay), AOAC International, Gaithersburg, Maryland.

Bava, L., Zucali, M., Sandrucci, A., Brasca, M., Vanoni, L., Zanini, L., \& Tamburini, A. (2011). Effect of cleaning procedure and hygienic condition of milking equipment on bacterial count of bulk tank milk, J. of Dairy Research, 78, 211-219.

Blodgett, R., (2010). Most probable number from serial dilution. Appendix 2 in U.S. Food and Drug Administration, Bacteriological Analytical Manual (BAM).

BSTI (2002) BDS 1702:2002. Bangladesh Standard: Specification for Pasteurized Milk. pp. 2-3, Bangladesh Standards and Testing Institution, Tejgaon Industrial Area, Dhaka.

Bukuku, J.N. (2013). Awareness of health risks as a result of consumption of raw milk in Arusha City and Meru District, Tanzania. Unpublished dissertation for award of MSc. degree at Sokoine University of Agriculture, Morogoro, Tanzania, 1-89.

Coitinho, T. B., Cassoli, L. D., Cerqueira, P. H. R., da Silva, H. K., Coitinho, J. B., \& Machado, P. F. (2017). Adulteration identification in raw milk using Fourier transforms infrared spectroscopy. Journal of Food Science and Technology, 54(8), 2394-2402.

Dehinenet, G., Mekonnen, H., Ashenafi, M. \& Emmanuelle, G. (2013). Determinants of raw milk quality under a smallholder production system in selected areas of Amhara and Oromia National Regional States, Ethiopia, Agric. Biol. J. N. Am., 4(1), 84-90.

Dey, S. \& Karim, M. H. (2013). Study on physicochemical and microbial quality of available raw, pasteurized and UHT milk during preservation, Int. J. Sci. Invent. Today, 2 (2): 150-157.

EL-zubeir, IEM, \& Ahmed, M.I. (2007). The hygienic quality of raw milk produced by some dairy farms in Khartoum-Sudan. J. Microbiol., 2, 988-991.

Erdogrul, O. \& Erbilir, F. (2006). Isolation and Characterization of Lactobacillus bulgaricus and Lactobacillus casei from various foods. Turk. J. Biol., 30, 39-44.

Faraz, A., Lateef, M., Mustafa, M. I., Akhtar, P., Yaqoob, M. \& Rehman, S. (2013). Detection of Adulteration, Chemical Composition and Hygienic Status of Milk Supplied to Various Canteens Of Educational Institutes And Public Places In Faisalabad, The Journal of Animal and Plant Sciences, 23, 119-124.

Gandy, A. L., Schilling, M. W., Coggins, P. C., White, C. H., Yoon, Y. and Kamadia, V. V. (2008). The effect of pasteurization temperature on consumer acceptability, sensory characteristics, volatile compound composition, and shelf-life of fluid milk, J. Dairy Sci., 91(5), 1769-1777.

Ghasemi-Varnamkhasti, M., Ghatreh-Samani, N., Naderi-Boldaji, M., Forina, M., \& Bonyadian, M. (2017). Development of two dielectric sensors coupled with computational techniques for detecting milk adulteration. Computers and Electronics in Agriculture, 140, 266-278.

Giffel, M.C. te, Wagendorp, A., Herrewegh, A. \& Driehuis, F. (2002). Bacterial spores in silage and raw milk, Antonie van Leeuwenhoek, 81, 625-630.

Hossain, T. J., Alam, K. and Sikdar, D. (2010). Chemical and microbiological quality assessment of raw and processed liquid market milks of Bangladesh, Res. J. Dairy Sci., 4(4), 28-34.

Huck, J.R., Hammond, B.H., Murphy, S.C., Woodcock, N.H. \& Boor, K.J. (2007). Tracking spore-forming bacterial contaminants in fluid milk-processing systems, J. Dairy Sci., 90, 4872-4883.

Iqbal, M. Ishfaq, M N Abbas, A. Wahab, M Qayum, S Mehsud. Pathogenic bacteria and heavy metals toxicity assessments in evaluating unpasteurized raw milk quality through biochemical tests collected from dairy cows, Asian Pac J Trop Dis, 2016, 6(11), 868-872.

Islam, A., Ahmed, S., \& Masum, A. K. M. (2016). Quality evaluation of raw milk collected from local markets at Madhupur upazila of Tangail district. Fundamental and Applied Agriculture, 1(2), 70-74.

Islam, M. A., Sarker, M. T., Prabakusuma, A. S., Russel, M. I. H., \& Islam, M. S. (2018). Detection of Adulteration and Quality Evaluation of Raw Milk Collected from Local Markets in Bangladesh, Food Biology, 7, 08-13.

Ivy, R. A., Ranieri, M. L., Martin, N. H., Bakker, H. C. den, Xavier, B. M., Wiedmann, M. \& Boor, K. J. (2012). Identification and characterization of psychrotolerant sporeformers associated with fluid milk production and processing, Appl. Environ. Microbiol., 78, 1853-1864.

Khaton, R., Hasnat, M. A., Rahman, S. \& Rahman, M. M. (2014). Public health safety in relation to microbiological quality of freshly drawn cow's milk in Bangladesh, Bangl. J. Vet. Med., 2014, 12 (2), 231236.

Kivaria, F.M., Noordhuizen, J.P.T.M. \& Kapaga, A.M. (2006). Evaluation of the hygienic quality and associated public health hazards of raw milk marketed by smallholder dairy producers in the Dar es Salaam region, Tanzania, Tropical Animal Health Production, 38, 185-194.

Lues, J. F. R., Beer, H. De, Jacoby, A., Jansen, K. E \& Shale, K. (2010). Microbial quality of milk, produced by small scale farmers in a peri-urban area in South Africa, African Journal of Microbiology Research, 4(17), 1823-1830. 
Marjan S., Das, K. K., Munshi, S. K., \& Noor, R. (2014). Drug-resistant bacterial pathogens in milk and some milk products, Nutn. Food Sci., 44(3), 241-248.

Masiello, S.N., Martin, N.H., Watters, R.D., Galton, D.M., Schukken, Y.H., Wiedmann, M., \& Boor, K.J. (2014). Identification of dairy farm management practices associated with the presence of psychrotolerant sporeformers in bulk tank milk, J. Dairy Sci., 97, 4083-4096.

Miller, R.A., Kent, D.J., Boor, K.J., Martin, N.H., \& Wiedmann, M. (2015). Different management practices are associated with mesophilic and thermophilic spore levels in bulk tank raw milk, J. Dairy Sci., 98, 4338-4351.

Monem, P. K. (2012). Quality of raw milk available at different markets of Bogra town. M.S Thesis, Department of Dairy Science, Bangladesh Agricultural University, Mymensingh.

Motta, T. M. C., Hoff, R. B., Barreto, F., Andrade, R. B. S., Lorenzini, D. M., Meneghini, L. Z., \& Pizzolato, T. M. (2014). Detection and confirmation of milk adulteration with cheese whey using proteomic-like sample preparation and liquid chromatography-electrospray-tandem mass spectrometry analysis, Talanta, 120, 498505 .

Murphy, S. C., Martin, N. H., Barbano, D. M., \& Wiedmann, M. (2016). Influence of raw milk quality on processed dairy products: How do raw milk quality test results relate to product quality and yield? J. Dairy Sci., 99, 10128-10149.

Nanu, E., Latha, C., Sunil, B., Prejit, Thomas M. \& Venon, K.V. (2007). Quality assurance and public health safety of raw milk at the production point, Am. J. Food Technol, 2, 145-152.

Nicolaou, N., Xu Y., Goodacre, R. (2011). MALDI-MS and multivariate analysis for the detection and quantification of different milk species. Anal Bioanal Chem, 399, 3491-3502.

Parekh, T.S. \& Subhash, R. (2008). Molecular and bacteriological examination of milk from different milch animals with special reference to Coliforms, Current Research in Bacteriology, 1(2), 56-63.

Popescu, A. \& Angel, E. (2009). Analysis of milk quality and its importance for milk processors, Lucrări Ştiinţifice Zootehnie Si Biotehnologii, 42(1), 501-503.

Popescu, S., Borda, C., Diugan, E. A. \& Oros, D. (2014). Assessing the Hygienic Quality of Raw Cow Milk from Transylvanian Farms, Animal Science and Biotechnologies, 47(2), 172-175.

Prodhan, U. K., Alam, M. J., Sadia, M. K., Sultana, S., Hye, M. A., Ahamed, M. S. (2016). Study on the quality of commercial market milk available in Bangladesh, Annals. Food Science and Technology, 17(2), 293-298.

Rashedul, M. D. (2012). Study on the quality evaluation and detection of adulteration of raw milk at Fulbaria upazila of Mymensingh district. MS Thesis, Department of Dairy Science, Bangladesh Agricultural University, Mymensingh.

Salman, Adil M. A. \& Hamad, Iman M. (2011). Enumeration and identification of Coliform bacteria from raw milk in Khartoum State, Sudan, Journal of Cell and Animal Biology, 5(7), 121-128.

Scheldeman, P., Herman, L., Foster, S. \& Heyndrickx, M. (2006). Bacillus sporothermodurans and other highly heat-resistant spore formers in milk, J. Appl. Microbiol., 101, 542-555.

Shojaei, ZA \& Yadollahi, A. (2008). Physiochemical and Microbiological Quality of raw milk, Pasteurized and UHT milks in Shops, Asian J. Sci. Res., 1(5), 532-538.

Shrishti, N., Rakesh, P., \& Nishant, R. (2013). Analysis of Milk Quality, Adulteration and Mastitis in Milk Samples Collected from Different Regions of Dehradun, International Journal of Pharm Tech Research, 5(2), 359364.

Teklemichael, T., Ameha, K. \& Eyassu, S.(2015). Physico Chemical Properties of Cow Milk Produced and Marketed in Dire Dawa Town, Eastern Ethiopia, Journal of Food Science and Quality Management, 42, 5661.

Uma, R., Chandrakanth, N., Indu, Priya S, Venkata, Nagalakshmi R. \& Usha, K. B. (2009). Isolation and characterization of faecal coliforms in street vended fruit juices and its safety evaluation: a case study of Bellary city, India, Internet Journal of Food Safety, 11, 35-43. 